\title{
The confirmed occurrence of two specimens of Remora remora (Linnaeus, 1758) from Mersin Bay (NE Mediterranean, Turkey)
}

\section{Deniz ERGÜDEN ${ }^{1}$, Deniz AYAS ${ }^{2}$}

Cite this article as:

Ergüden, D., Ayas, D. (2021). The confirmed occurrence of two specimens of Remora remora (Linnaeus, 1758) from Mersin Bay (Ne Mediterranean, Turkey). Aquatic Research, 4(3), 293-298. https://doi.org/10.3153/AR21023

${ }^{1}$ University of Iskenderun Technical, Faculty of Marine Science and Technology, Iskenderun, Hatay, Turkey

${ }^{2}$ University of Mersin, Faculty of Fisheries, Mersin, Turkey

\section{ORCID IDs of the author(s):}

D.E. $0000-0002-7682-6867$

D.A. $0000-0001-6762-6284$

Submitted: 23.08 .2020

Revision requested: 14.12 .2020

Last revision received: 15.12 .2020

Accepted: 15.12.2020

Published online: 16.05.2021

Correspondence:

Deniz ERGÜDEN

E-mail: deniz.erguden@iste.edu.tr

\begin{abstract}
Remoras attach to sharks, big fish, and sea turtles and continue their lives with these creatures. Kapızlı and Tekeli beaches are located near Göksu Delta and Anamur nesting areas of Caretta caretta. In this study, two Remora individuals were caught with a fishing rod in July, when the ovulation was most intense. The smaller remora individual $(33 \mathrm{~cm})$ was caught from the coast of Tekeli with the chicken breast at a depth of $2.5 \mathrm{~m}$, and the larger one $(66 \mathrm{~cm})$ with bread at a depth of $1.5 \mathrm{~m}$ from Kapizlı beach on 24.07.2020. The two Remora individuals caught were probably attached to the sea turtles. However, probably due to sea turtles going to the beach to lay eggs, Remoras started to free-swimming, and they were caught with the fishing line since they could not be fed. The present study reported that the first occurrence of Remora specimens is probably attached to turtles for Turkey's northeastern Mediterranean coast. Besides, this study is provided some morphometric and meristic data on this species and discussed a probable host of these specimens.
\end{abstract}

Keywords: Echeneidae, Shark sucker, Record, Mediterranean Sea, Turkey

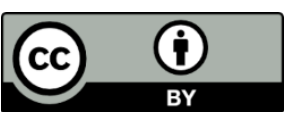

(C) 2021 The Author(s) 


\section{Introduction}

The family Echeneidae is represented in the Mediterranean Sea by two genera Echeneis (Sucking disc with 18 to 28 laminae), Remora (Pelvic fins broadly attached to the abdomen; disc laminae 16 to 20), and four species of live sharksucker Echeneis naucrates Linnaeus, 1758, Whalesucker Remora australis (Bennett, 1840), Marlin sucker Remora osteochir (Cuvier, 1829), and Shark sucker Remora remora (Linneaus, 1758) (Bilecenoglu et al., 2014; Stamouli et al., 2018; Tuncer et al., 2012).

The sucking disc easily distinguishes $R$. remora on the top of the head, which represents a modification of the spinous dorsal fin. It is a globally distributed, epipelagic species found to a maximum depth of $200 \mathrm{~m}$ (Fricke et al., 2011) in tropical to warm temperate waters in the western and eastern Pacific, western and eastern Atlantic, including the Mediterranean (Fishbase, 2020). This species is frequently associated with sharks, large fishes, turtles, and occasionally free-swimming (Eschmeyer et al., 1983; Mundy, 2005). It feeds mainly on scraps resulting from the feeding activities of their host and sometimes feed on parasitic copepods (Muus \& Nielsen, 1999).

Remora species may attach to a diverse array of host types. Remoras probably are benefited from this association in several ways, including transport, feeding opportunities, and protection from some predators (Alling, 1985; Fertl \& Landry, 2002; O'Toole, 2002).

This study aimed to document the first confirmed record of two specimens of $R$. remora for the northeastern Mediterranean coast of Turkey. Besides, provide some morphometric and meristic data on the species and discuss a probable host of this specimen.

\section{Material and Methods}

One specimen of the $R$. remora was caught with a fishing rod at a depth of $1.5 \mathrm{~m}$ in the Kapizlı $\left(36^{\circ} 24^{\prime} 11.0^{\prime \prime} \mathrm{N}\right.$ $34^{\circ} 04^{\prime} 44.4^{\prime \prime E}$ ) (Figure 1), and other specimen was caught by a fishing rod at a depth of $2.5 \mathrm{~m}$ on Tekeli coast (Coordinate: $\left.36^{\circ} 07^{\prime} 55.0^{\prime \prime} \mathrm{N}-33^{\circ} 07^{\prime} 39.2^{\prime \prime E}\right)$ Mersin Bay on 24 July 2020 (Figure 2). Sampling points of the species in Turkey's Eastern Mediterranean Sea coast is presented in the map (Figure 3). These specimens were immediately transported to the laboratory for a more detailed examination. Morphometric measurements of the samples were made to the nearest $0.1 \mathrm{~mm}$ using a digital caliper and weighed to the nearest gram (g). All measurements, counts, and morphological characters agree with those of Muus \& Nielsen (1999). These specimens were preserved in $4 \%$ formaldehyde and deposited in the $\mathrm{Mu}$ seum of the Systematic, Faculty of Fisheries, Mersin University, (catalog number: MEUFC-20-11-131).

\section{Results and Discussion}

The specimens of $R$. remora, $33.0 \mathrm{~cm}$ and $66.0 \mathrm{~cm}$ in total length and 356 and $1665 \mathrm{~g}$ in weight, presented the following meristic characters: dorsal fin rays 21-23, anal-fin rays 21-22, pectoral fin rays 25-26, and suction disc laminae (modified first dorsal fin), 19-22 (Table 1).

Body elongate and robust. Head depressed. Head with a sucking disc which does not extend posteriorly as far as the end of depressed pectoral fin short and round. Caudal fin emarginate and caudal peduncle thick. Scales minute and indistinct. Disc extending more or less to the distal end of the pectoral fin. Lower jaw extending beyond the upper jaw. Teeth on jaws, palatines, vomer, and tongue. Dorsal and anal fins are originating well behind the middle of standard length, low, longest ray about 6th (Paulin \& Habib, 1982).

The morphometric data gave the following ratios, as a percent (\%) of Standard Length (SL) or Head Length (HL): body depth 7.3-7.4, head length 70.0-69.7, predorsal length 32.933.0, preanal length 74.5-74.9, caudal peduncle length 3.33.4, all in SL; eye diameter 8.8-9.6, preorbital distance 42.643.7, postorbital distance 39.7-40.8, all in HL. The morphometric measurements and meristic counts of $R$. remora were indicated in Table 1 and compared to previous reports from New Zeland (Paulin \& Habib, 1982) from Irish waters (Quickley et al., 1994). Morphological data of $R$. remora are consistent with measurements and counts reported by other authors describing this species (Muus \& Nielsen 1999; Paulin \& Habib, 1982; Quickley et al., 1994), with minor differences.

The color of fresh specimens was the body brown, and the sucker disk contained light brown and dark brown stripes. The edge lower sides of the body were colored light grey-blue strips.

Remoras select a wide variety of large fishes, reptiles, cetaceans, and some species as hosts or attach themselves to floating objects. This species shows considerable host specificity (Strasburg, 1964; Lachner, 1966). According to Nelson (1976), the Remora specimens have pressed the disc against its intended host and adheres by the partial vacuum created by operating the disc ridges like slats in a Venetian blind. 
Table 1. Morphometric $(\mathrm{mm})$ and meristic characteristic of the $R$. remora specimens from the Northeastern Mediterranean (Mersin Bay, Turkey) compared with and compared with previous record (Paulin \& Habib, 1982 and Quickley et al., 1994)

\begin{tabular}{|c|c|c|c|}
\hline \multirow[t]{2}{*}{ Measurements } & \multicolumn{2}{|c|}{ Values (cm) } & \multirow[b]{2}{*}{$\begin{array}{c}\text { Quickley et al. (1994) } \\
(n=1)\end{array}$} \\
\hline & $\begin{array}{l}\text { This Study } \\
(\mathrm{n}=2)\end{array}$ & $\begin{array}{l}\text { Paulin \& Habib (1982) } \\
(n=36)\end{array}$ & \\
\hline Total length & $33.0-66.0$ & - & 36.5 \\
\hline Standart length & $26.7-53.5$ & $6.0-26.5$ & 29.5 \\
\hline Head length & $6.8-13.5$ & $2.6-3.0$ & 7.5 \\
\hline Body depth & $1.9-3.9$ & $1.3-1.6$ & - \\
\hline Disc length & $4.8-9.6$ & $3.2-3.9$ & 9.5 \\
\hline Disc width & $2.5-4.9$ & $1.4-2.0$ & 4.3 \\
\hline Eye diameter & $0.6-1.3$ & $0.3-0.5$ & - \\
\hline Preorbital distance & $2.9-5.9$ & - & - \\
\hline Postorbital distance & $2.7-5.5$ & - & - \\
\hline Dorsal fin length & $4.0-8.0$ & $2.6-3.2$ & - \\
\hline Predorsal length & $8.8-17.7$ & $6.2-7.0$ & - \\
\hline Preanal length & $20.0-40.0$ & - & - \\
\hline Caudal peduncle length & $0.9-1.8$ & $0.5-.0 .7$ & - \\
\hline Dorsal fin rays & $21-23$ & $20-24$ & 21 \\
\hline Anal fin rays & $21-22$ & - & 21 \\
\hline Pectoral fin rays & $25-26$ & - & 25 \\
\hline Disc laminae & $19-22$ & $16-18$ & 17 \\
\hline
\end{tabular}

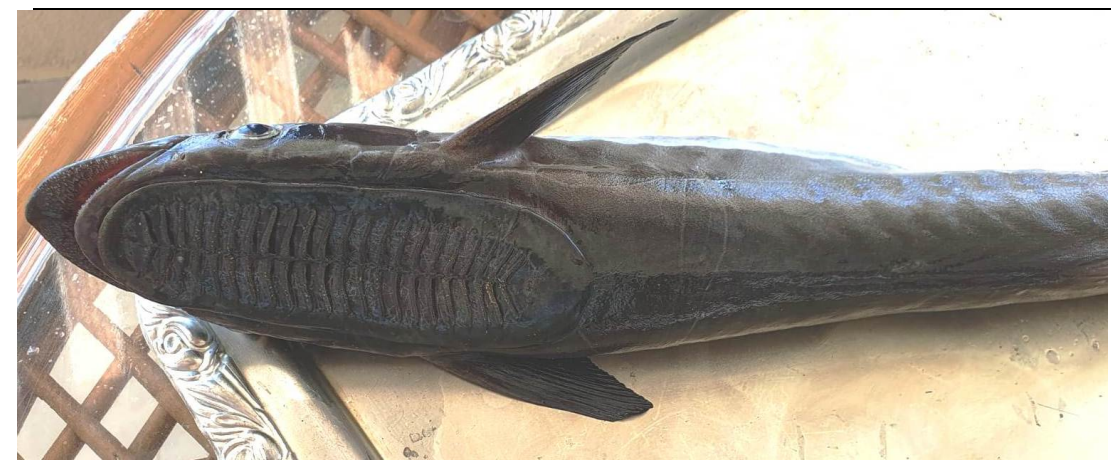

Figure 1. A specimen of Remora remora $66 \mathrm{~cm}$ TL, in Kapızlı, Mersin Bay

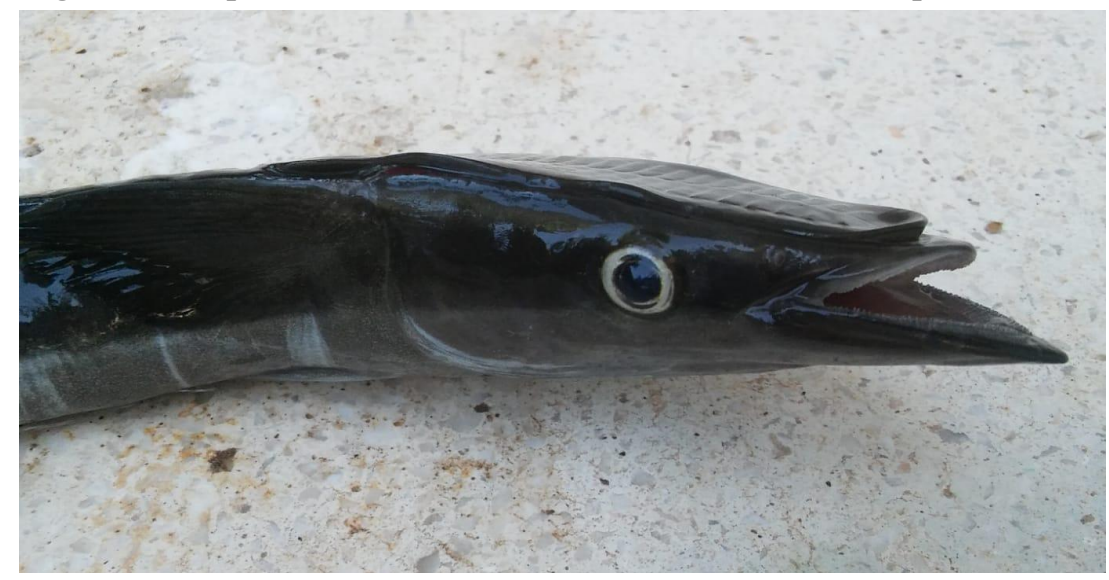

Figure 2. A specimen of Remora remora $33 \mathrm{~cm}$ TL, in Tekeli, Mersin Bay 
Remora remora lives more active as parasite pickers (Smith, 1997) and can reach up to $86.4 \mathrm{~cm}$ (Claro, 1994) and commonly occur $40 \mathrm{~cm}$ in total length, TL (Sanches, 1991). Froese \& Pauly (2020) suggested that its maximum published weight was $1100 \mathrm{~g}$ (IGFA, 2001) for this species.

According to O'Toole (2002), Remoras (Echeneidae) are known to attach to several types of marine vertebrates, including fishes (large teleost fish and sharks), turtles, and mammals. However, they sometimes can be free swimming. Lachner (1966) is reported that several genera and species of sharks and large teleost's as hosts for this species, and he stated that in his study, the hosts to which Remora specimens collected by the purse-seiner were attached to could not be recorded because when the Remoras are taken out of the water, they detach themselves from the host. Besides, a few researchers (Kaspiris \& Ondrias, 1984; O'Toole, 2002) reported samples of $R$. remora found with attached on a turtle in the southeast Aegean Sea.

Kapızlı and Tekeli coasts are located near Anamur and Göksu Delta, the significant nesting areas of Mersin, which allows Caretta careatta turtles to go out on the beaches and lay their eggs (Türkozan \& Kaska, 2010). In this study, two Remora individuals caught were probably be attached to the sea turtles. It is assumed that $R$. remora samples caught by fishing rod probably free swimming when caught. Similarly, Phillipps (1964) are reported the recording of $R$. remora individuals is associated with the marlins, Caretta caretta turtle, and the blue shark in New Zealand waters.

Fretey $(1978,1979)$ had observed specimens of $R$. remora in the French Guiana coast accompanying a female leatherback turtle onto the beach during the nesting season. Result of this study, he had informed that although some of the Remoras died from dehydration, others actually survived and again returned to the sea still attached to their hosts. Similarly, Quickley et al. (1994) reported six $R$. remora specimens had been recorded in association with leatherback turtles Dermochelys coriacea in Irish waters 1980's. Also, Quickley et al. (1994) declared that about the occurrence of both species with together along the south Irish coast and even in northern European waters by several researchers (Angel, 1922; Bouxin et al., 1933; Brongersma, 1967, 1972; Wheeler, 1969, 1978; Whitehead et al., 1986) in previous years.

\section{Conclusion}

In the present study, two Remora individuals captured are probably associated with the Caretta caretta turtles. However, we think that because the turtles go to the beach for nesting, the Remoras may tend to free swimming, and due to they cannot be fed, they probably are caught by fishing rods.

\section{Compliance with Ethical Standard}

Conflict of interests: The authors declare that for this article they have no actual, potential or perceived conflict of interests.

Ethics committee approval: Approved by institutional, regional and national animal ethical statements.

\section{Funding disclosure: -}

Acknowledgments: The authors would like to thank the fishers for providing the specimens of Remora remora.

\section{Disclosure: -}

\section{References}

Alling, A. (1985). Remoras and blue whales: a commensal or mutual interaction? Whalewatcher -Journal of the American Cetacean Society, 19, 6-19.

Angel, F. (1922). Description d'une tortue-luth (Dermochelys coriacea Linne.) peches aupres de Biarritz (Basses-Pyrenees). Bulletin du Muséum National d'Histoire Naturelle (Paris), 1922, 481-483.

Bilecenoglu, M., Kaya, M., Cihangir, B., Çiçek, E. (2014). An updated checklist of the marine fishes of Turkey. Turkish Journal of Zoology, 38, 901-929.

https://doi.org/10.3906/zoo-1405-60

Bouxin, J., Bouxin, H., Legendre, R. (1930). Capture d'une tortue luth (Dermochelys coriacea L.), accompagnee de pilotes (Naucrates ductor L.) et de remoras (Echeneis remora L.) pres de Pile aux Moutons. Bulletin de le Soci Zoologique de France, 6, 521-528.

Brongersma, L.D. (1967). Guide for the identification of stranded turtles on British coasts. British Museum Natural History London, 695, 1-22.

Brongersma, L.D. (1972). European Atlantic turtles. Zoologische Verhandelingen (Leiden), 121, 1-318.

Claro, R. (1994). Características generales de la ictiofauna. In R. Claro (Ed.,) Ecología de los peces marinos de Cuba (p. 55-70). Instituto de Oceanología Academia de Ciencias de Cuba and Centro de Investigaciones de Quintana Roo.

Eschmeyer, W.N., Herald, E.S., Hammann, H. (1983). A field guide to Pacific coast fishes of North America. Boston (MA, USA): Houghton Mifflin Company. xii+ 336 p. 
Fertl, D., Landry Jr. A.M. (2002). Remoras. In W.F. Perrin, B. Würsig \& J.G.M. Thewissen (Eds.), Encyclopedia of Marine Mammals (p. 1013-1015). 1414 pp. New York, NY: Academic Press.

Fretey, J. (1978). Accompagnement a terre de tortue luths, Dermochelys coriacea (Linne.) par des Remoras. Revue Francais d'Aquariologie, 5(2), 49-54.

Fretey, J. (1979). Commensalisme entre Remora remora (L.) et des tortues marines pendant la nidification. Cybium, 7(3), 40 .

Fricke, R., Kulbicki, M., Wantiez, L. (2011). Checklist of the fishes of New Caledonia, and their distribution in the Southwest Pacific Ocean (Pisces). Stuttgarter Beiträge zur Naturkunde A, Neue Serie 4, 341-463.

Froese, R., Pauly, D. (2020). Fishbase. Worldwide Web Electronic Publication. Retrieved from http://www.fishbase.org (accessed 30.04.2020).

IGFA, (2001). Database of IGFA angling records until 2001. IGFA, Fort Lauderdale, USA.

IUCN, (2020). Red List of Threatened Species. Version 2020-1. Retrieved from http://www.iucnredlist.org (accessed 02.02.2020).

Kaspiris, P., Ondrias, J. (1984). Some rare fishes from the Greek Sea waters. Biljeske - Notes 61, 1-4.

Lachner, E.P. (1966). Family Echeneidae: disc fishes. In L.P. et al. Shultz (Eds), Fishes of the Marshall and Mariana Islands (p. 74-80). USA: United States National Museum Bulletin.

Lachner, E.A., Post, A. (1990). Echeneidae. In J.C. Quéro, J.C. Hureau, C. Karrer, A. Post \& L. Saldanha (Eds.), Checklist of the fishes of the eastern tropical Atlantic (CLOFETA) (p. 725-728). Vol. 2. JNICT, Lisbon; SEI, Paris; and UNESCO, Paris.

Mundy, B.C. (2005). Checklist of the fishes of the Hawaiian Archipelago. Bishop Museum Bulletin in Zoology, 6, 1-704.

Muus, B.J., Nielsen, J.G. (1999). Sea fish. 340 pp. Scandinavian Fishing Year Book, Denmark: Hedehusene, ISBN: 8790787-00-5
Nelson, J.S. (1976). Fishes of the world. 416 pp. New York, John Wiley and Sons, ISBN: 0-471-01497-4,

O'Toole, B. (2002). Phylogeny of the species of the superfamily Echeneoidea (Perciformes: Carangoidei: Echeneidae, Rachycentridae, and Coryphaenidae), with an interpretation of echeneid hitchhiking behaviour. Canadian Journal of Zoology, 80, 596-623.

https://doi.org/10.1139/z02-031

Paulin, C.D., Habib, G. (1982). Remoras (Pisces: Echeneidae) from New Zealand, New Zealand Journal of Zoology, 9(1), 33-36.

https://doi.org/10.1080/03014223.1982.10423834

Phillipps, W.J. (1964). The occurrence of remora in Cook Strait. Records of the Dominion Museum, 5(10), 74-75.

Quigley, D.T.G., Flannery, K., O'Shea, J. (1994). Remora remora remora L. in Irish waters: Further records and a review of Irish records The Irish Naturalists' Journal, 24(12), 499-502.

Sanches, J.G. (1991). Catálogo dos principais peixes marinhos da República de Guiné-Bissau. Publ. Invest. Pescas: Avuls. Inst. Nac., Num. 16, 429 pp.

Smith, C.L. (1997). National Audubon Society field guide to tropical marine fishes of the Caribbean, the Gulf of Mexico, Florida, the Bahamas, and Bermuda. 720 pp. New York: Alfred A. Knopf, Inc., ISBN; 9780679446019

Stamouli, C., Akel, E., Azzurro, E., Bakiu, R., Bas, A., Bitar, G., Boyacı, Y., Cakall, M., Corsini-Foka, M., Crocetta, F., Dragičević, B., Dulčić, J., Durucan, F., Zrelli, R., Erguden, D., Filiz, H., Giardina, F., Giovos, I., Gönülal, O., Hemida, F., Kassar, A., Kondylatos, G., Macalı, A., Mancini, E., Ovalis, P., Paladini De Mendoza, F., Pavičič, M., Rabaoui, L., Rizkalla, S., Tiralongo, F., Turan, C., Vrdoljak, D., Yapıcı, S., Zenetos, A. (2018). New Mediterranean Biodiversity Records (December 2017). Mediterranean Marine Science, 18(3), 534-556.

https://doi.org/10.12681/mms.15823

Tuncer, S., A. Orlov, M., Ozen, O. (2012). First record of marlin sucker, Remora osteochir (Cuvier, 1829), from the Northeastern Aegean Sea, Turkey. Journal of Ichthyology, 52(6), 400-408.

https://doi.org/10.1134/S0032945212040145 
Türkozan, O., Kaska, Y. (2010). Turkey. In P. Casale \& D. Margaritoulis (Eds.), Sea turtles in the Mediterranean: distribution, threats and conservation priorities (p. 257-293). Switzerland: IUCN/SSC Marine Turtle Specialist Group, Gland. ISBN: 978-2-8317-1240-6

Wheeler, A.C. (1969). Fishes of the British Isles and northwest Europe. London: Macmillan, p. 1-613, ISBN: 10: 0333059557
Wheeler, A.C. (1978). Key to the fishes of northern Europe. London: Frederick Warne, p. 1-380, ISBN: 10: 0723220646

Whitehead, P.J.P., Bauchot, M.L., Hureau, J.C., Nielsen, J., Tortonese, E. (1986). Fishes of the north-eastern Atlantic and the Mediterranean. Vol. 3, Paris: Unesco, p. 1329-1334, ISBN: 92-3-002215-2 